\title{
Exoskeletal structures and ultrastructures in Lower Devonian dalmanitid trilobites of the Prague Basin (Czech Republic)
}

\author{
PETR BUDIL \& FRANTIŠEK HÖRBINGER
}

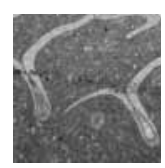

\begin{abstract}
Our current studies of the exoskeletal structures and ultrastructures in Lower Devonian dalmanitid trilobites of the Prague Basin are briefly described and discussed. The interior of the exoskeleton in most specimens from the Prague Basin is recrystallised and largely filled with very fine homogeneous sparitic cement. The ultrastructures sensu stricto, e.g., the lamination, layers forming the exoskeleton, and the fine pores or "Osmólska" cavities, are mostly imperceptible even at higher magnifications. However, ultrastructural relics were observed in some polished thin sections and exoskeletal fragments using electron microscopy. Larger structures, especially the eyes, the megapores penetrating the exoskeleton, and the surface sculptures (prosopon sensu Gill 1949), are relatively well preserved and show very fine details. The biological significance of megapores is briefly discussed. Modification of the inner parts of the exoskeletons by diagenetic processes, obscuring most of the fine internal structures, is evident. $\bullet$ Key words: Trilobita, Dalmanitidae, exoskeleton microstructure.
\end{abstract}

BUDIL, P. \& HÖRBINGER, F. 2007. Exoskeletal structures and ultrastructures in Lower Devonian dalmanitid trilobites of the Prague Basin (Czech Republic). Bulletin of Geosciences 82(1), 27-36 (4 figures, 1 table). Czech Geological Survey, Prague. ISSN 1214-1119. Manuscript received January 17, 2007; accepted in revised form March 7, 2007; issued March 30, 2007. • DOI 10.3140/bull.geosci.2007.01.27

Petr Budil, Czech Geological Survey, Klárov 3, 118 21, Praha 1, Czech Republic; budil@ cgu.cz•František Hörbinger, Ke Zdravotnimu středisku 120, 15500 Praha 5, Czech Republic; Frantisek.Horbinger@cuzk.cz.

The inner and outer fine structures and ultrastructures of the trilobite exoskeleton, including visual organs, have been studied since the end of the nineteenth and the first half of the twentieth century (Lindström 1901, Størmer 1930). However, modern equipment such as the electron microscope and X-ray analysis have proved to be very useful in the investigation of these structures since 1960. This especially concerns the distinction of diagenetic structures from the original constitution of the exoskeleton and the finest ultrastructure of the exoskeletal fabric (see Dalingwater 1973; Osmólska 1975; Teigler \& Towe 1975; Miller 1976; Dalingwater \& Miller 1977; Miller \& Clarkson 1980; Dalingwater et al. 1993, 1991; Størmer 1980; Mutvei 1981; McAllister \& Brand 1989; Wilmot \& Fallick 1989; Wilmot 1990a, b; Fortey \& Wilmot 1991). These investigations were reviewed and discussed in detail by Whittington \& Wilmot in Kaesler et al. (1997) and by Fortey \& Owens (1999). Aside from the excellent studies of eyes in Ananaspis Campbell, 1967, Reedops R. \& E. Richter, 1925 and Ormathops Delo, 1935 undertaken by Clarkson (1969, 1971), and some comparative studies of Dalmanitina Reed, 1905 (Clarkson 1968, Clarkson \& Levi-Setti 1975, Levi-Setti 1993, Horváth \& Clarkson
1993), only a few papers have discussed this topic using the rich and apparently well preserved trilobite material from the Prague Basin (Barrandian area, Czech Republic). Šnajdr (1980, 1985, 1987) and Chlupáč (1977) employed the surface exoskeletal sculpture as a useful systematic feature, and also defined some new terms (for example "megapores" by Šnajdr 1985, 1987). Both authors discussed many of the surface structures in detail, but without using electron microscopy or thin sections for their study. Only one work, which is an unpublished thesis (Kasan 1997), deals in more detail with the sculpture of Bohemian Lower Devonian phacopid trilobites. In that thesis, electron microscope images were used for the first time in the study of trilobites (Pl. V, figs 1-8 in Kasan 1997), and the very poorly preserved, but probably present, lamination of the exoskeleton in Reedops decorus (Hawle \& Corda, 1847) was briefly discussed. In the present paper, the results of a test study of the presence of exoskeletal fine structures and ultrastructures in Lower Devonian dalmanitid trilobites are presented. This preliminary study accompanies the systematic revision of this group (Budil et al. in press), and therefore does not go into great detail. The present paper serves as an introduction and an asses- 
sment of the potential of the material for further study. Nevertheless, some of the observations discussed here provide new information on dalmanitid morphology. Some exoskeletal structures, including eye structures of Silurian and Devonian dalmanitid trilobites outside the Barrandian area, have already been discussed by previous authors, such as Campbell $(1975,1977)$ and Levi-Setti (1993).

\section{Provenance of the material and methods}

A total of seventy-six thin sections and thirteen electron microscope samples of the fourten species from the Praha and Zlíchov formations (Lower Devonian, Pragian and Emsian stages) have been studied (Tab. 1).

These species were selected as being representative of the twenty-five dalmanitid species present in this stratigraphic interval. Relatively simple methods were used in this initial stage of investigation. The polished and covered thin sections were observed under a NIKON SMZ 1500 optical microscope, while broken exoskeletal fragments (useful especially for the observation of fine surface details) were studied a with CamScan CS 3200 electron microscope. The samples selected for electron microscope observation were coated with $\mathrm{Au}-\mathrm{Pd}$ powder in a vacuum chamber. The methodology developed by Dalingwater \& Miller (1977) using etched polished thin sections or broken exoskeletal fragments with EDTA (disodium salt) was not used during this stage of the work. The use of such etching techniques and the testing of other methods is planned for a subsequent phase of the investigations, which will be focussed on inner exoskeletal ultrastructures. A short description of all figured specimens is presented in the next section and in the figure captions. All figured and cited samples are housed in the palaeontological collections of the Czech Geological Survey (CGS).
Table 1. A review of studied samples. Abbreviations: NP - Number of polished and covered thin sections, NS - Number of samples observed with electron microscope

\begin{tabular}{|c|c|c|c|}
\hline Species & Formation & NP & NS \\
\hline Odontochile hausmanni (Brongniart, 1822) & Praha & 24 & 1 \\
\hline Odontochile cristata Hawle \& Corda, 1847 & Praha & 8 & 2 \\
\hline Reussiana reussi (Barrande, 1846) & Praha & 3 & 1 \\
\hline $\begin{array}{l}\text { Zlichovaspis }(\text { Z.) rugosa rugosa (Hawle \& } \\
\text { Corda, 1847) }\end{array}$ & Praha & 7 & 0 \\
\hline Zlichovaspis (Z.) rugosa laura Šnajdr, 1985 & Praha & 11 & 1 \\
\hline Zlichovaspis (Z.) auriculata (Dalman, 1826) & Zlíchov & 5 & 2 \\
\hline Zlichovaspis (Z.) cf. marieva (Šnajdr, 1985) & Zlíchov & 4 & 0 \\
\hline $\begin{array}{l}\text { Zlichovaspis (Z.) spinifera spinifera } \\
\text { (Barrande, 1846) }\end{array}$ & Praha & 8 & 0 \\
\hline $\begin{array}{l}\text { Zlichovaspis (Z.) spinifera nomiona (Šnajdr, } \\
\text { 1987) }\end{array}$ & Praha & 0 & 1 \\
\hline $\begin{array}{l}\text { Zlichovaspis (Z.) vaneki nom. nud. (Budil et } \\
\text { al., in press) }\end{array}$ & Zlíchov & 0 & 1 \\
\hline $\begin{array}{l}\text { Zlichovaspis (Z.) tuberculata (Hawle \& } \\
\text { Corda, 1847) }\end{array}$ & Zlíchov & 2 & 0 \\
\hline $\begin{array}{l}\text { Zlichovaspis (Devonodontochile) maccoyi } \\
\text { (Barrande, 1852) }\end{array}$ & Zlíchov & 4 & 3 \\
\hline $\begin{array}{l}\text { Zlichovaspis (Devonodontochile) vigerle } \\
\text { (Šnajdr, 1987) }\end{array}$ & Zlíchov & 0 & 1 \\
\hline Zlichovaspis (Z.) sp. & Zlíchov & 1 & 0 \\
\hline
\end{tabular}

\section{Description and discussion}

\section{Exoskeletal fine structures and ultrastructures}

The internal structures of the exoskeleton in most of the samples have been almost entirely effaced by recrystallisation and by the homogeneous fine sparitic or microsparitic matrix that fills all spaces inside the former exoskeleton. So far, no absolutely certain remains of the prismatic outer layer (see Dalingwater et al. 1991) have been observed.

Figure 1. A - Odontochile hausmanni (Brongniart, 1822), Černá rokle near Kosoř, CGS PB 190. Vertical section through the pygidial axis, a detail of prominent interring processes (apodemes). $\times 5$. • B - Odontochile hausmanni (Brongniart, 1822), Velká Chuchle, Přídolí, CGS PB 191. Vertical section through the slightly disarticulated thorax at the margin of axial part, showing imbricated segments with prominent apodemes. $\times 6$. $\bullet \mathrm{C}-$ Odontochile cristata Hawle \& Corda, 1847, Praha-Konvárka, CGS PB 192. Vertical section through pygidium in axial part, the fine spiny granules possess a fine pore in the centre. $\times 36 . \cdot \mathrm{D}-$ Odontochile hausmanni (Brongniart, 1822), Černá rokle near Kosoř, CGS PB 193. Vertical section through the pygidial axis, a detail of the interring process. $\times 21$. E - Zlichovaspis (Devonodontochile) maccoyi (Barrande, 1852), Lužce, CGS PB 194. Vertical section through the pygidial axis with perceptible interring processes and with distinctive perforation of the exoskeleton by megapores. $\times 26$. $\bullet \mathrm{F}-$ Odontochile hausmanni (Brongniart, 1822), Velká Chuchle, Př́dolí, CGS PB 195. Detail of cross section of left pygidial margin with short fine spines and part of doublure. Note the "lamination" of the doublure (probably an artefact of polishing) in contrast with homogeneous structure of the dorsal exoskeleton. $\times 21$. $-\mathrm{G}-$ Zlichovaspis (Z.) rugosa laura Šnajdr, 1985, Branžovy near Loděnice, CGS PB 196. Vertical section through the pygidial axis, detail of prominent interring process. $\times 12 . \bullet H-$ Zlichovaspis $($ Z.) cf. marieva (Šnajdr, 1985), Švagerka, CGS PB 197. Vertical section through the pygidial axis with prominent interring processes. $\times 21 . \bullet \mathrm{I}, \mathrm{K}-\mathrm{N}-$ Odontochile hausmanni (Brongniart, 1822), Černá rokle near Kosoř, CGS PB 198. Vertical sections through the eyes, showing lenses separated by interlensal sclera. I $-\times 14, \mathrm{~K}-\times 36, \mathrm{~L}-\times 31, \mathrm{M}-\times 11, \mathrm{~N}-\times 11$. $・ \mathrm{~J}-$ Odontochile hausmanni (Brongniart, 1822), Černá rokle near Kosoř, CGS PB 198. A section through a free cheek, upturned doublure and remains of an eye. The false cross-oriented "laminae" are perceptible (probable artefact of polishing) $\times 18$. $\bullet$ - Odontochile hausmanni (Brongniart, 1822), Praha - Velká Chuchle, Př́ídolí, CGS PB 199. Vertical section through the damaged eye, showing lenses separated by interlensal sclera. $\times 15$. All specimens are from the Praha Formation (Lower Devonian, Pragian Stage), except for E and H, which are from the Zlíchov Formation (Lower Devonian, lower Emsian = Zlichovian Stage). 
Petr Budil \& František Hörbinger • Exoskeletal structures in Devonian dalmanitid trilobites
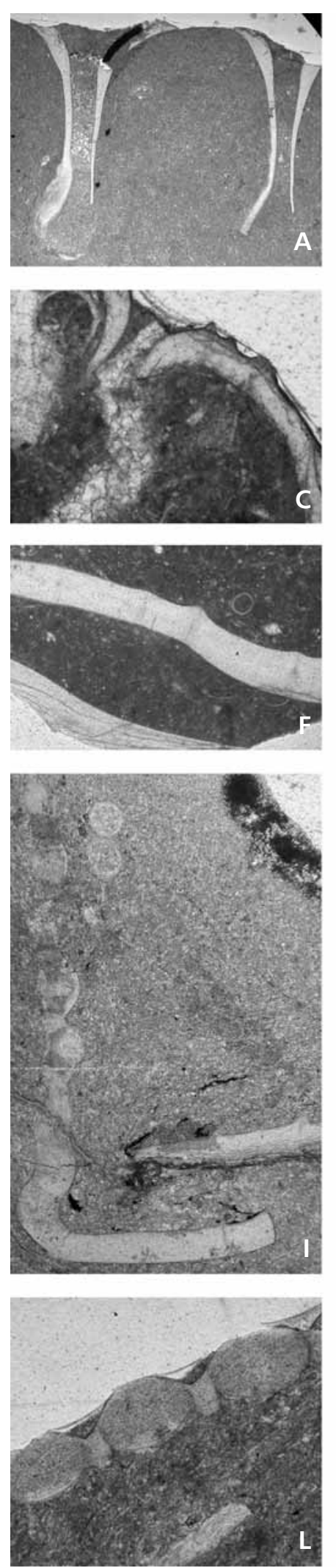
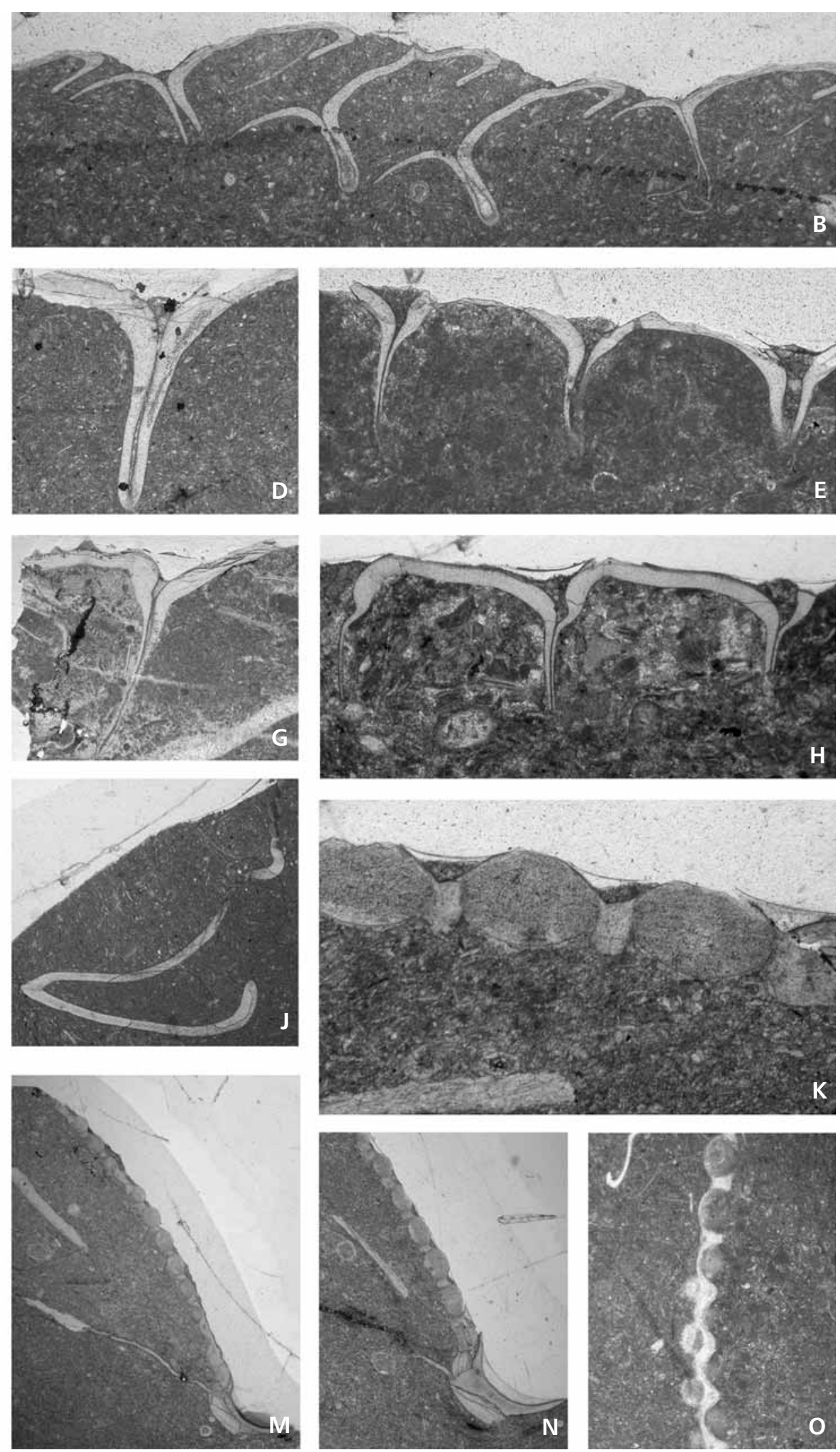

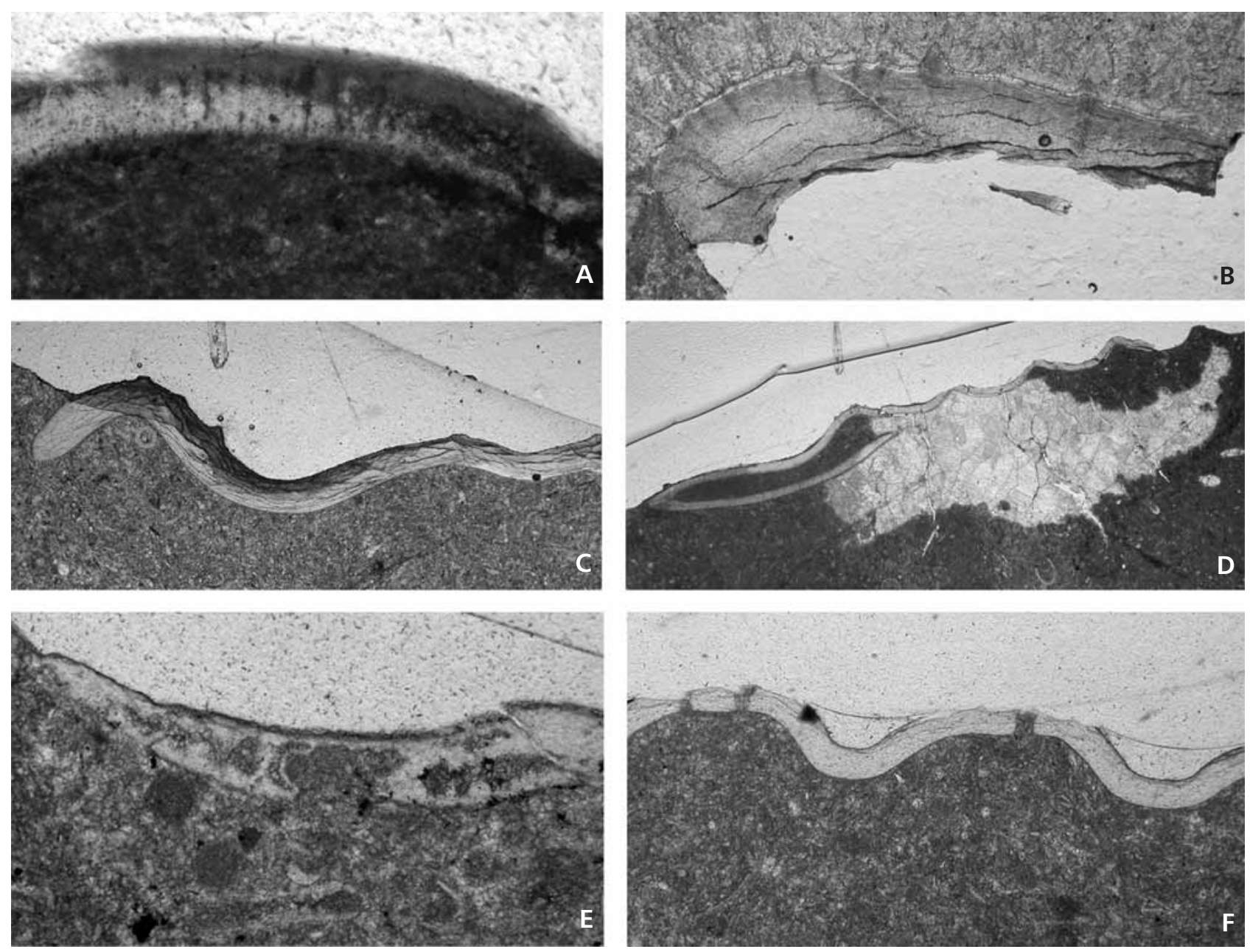

Figure 2. A - Zlichovaspis (Z.) auriculata (Dalman, 1826), Čeřinka near Bubovice, CGS PB 200. Vertical section through a strongly micritised exoskeleton, showing disctinctive fine perforation which, however, could have been made by boring sponges. $\times 42 . \bullet B-$ Zlichovaspis $(Z$.) sp., Branžovy near Loděnice, CGS PB 201. Vertical section through the thick exoskeleton with barely perceptible laminar structure of uncertain origin. Close-up of upper exoskeletal surface, a narrow layer possibly corresponding to the outer zone of the principal layer of the exoskeleton is developed. Some spines are finely perforated. $\times 31$. $\bullet$ C Odontochile cristata Hawle \& Corda, 1847, Lochkov, CGS PB 202a. A detail of a vertical section through the pygidium, some of the fine spiny granules possess a fine pore in the centre. Note the prominent irregular "laminae" which probably originated artificially during polishing. $\times 31 . \cdot \mathrm{D}-$ Odontochile cristata Hawle \& Corda, 1847, Praha-Konvárka, CGS PB 202b. A cross section through the pygidium, showing wide doublure. $\times 12$. $\bullet$ E - Zlichovaspis (Z.) rugosa laura Šnajdr, 1985, Branžovy near Loděnice, CGS PB 203. Vertical section through a strongly corroded pygidial exoskeleton, and a detail of a prominent cavern. $\times 36$. $• \mathrm{~F}$ - Zlichovaspis (Devonodontochile) maccoyi (Barrande, 1852 ), Lužce, CGS PB 204. Vertical section through the pygidial ribs showing distinctive perforation of elevated parts of exoskeleton by megapores. $\times 31$. All specimens are from the Praha Formation (Lower Devonian, Pragian Stage), except for A and F, which are from the Zlíchov Formation (Lower Devonian, lower Emsian = Zlichovian Stage).

Even the main subdivision into a laminated principal layer composed of three zones (an outer zone with narrow lamina units, a middle zone with a few relatively wide units, and an inner zone with a few narrow units) has not been unquestionably observed in Bohemian Lower Devonian dalmanitids. Though very rare structures reminiscent of fine laminae are locally preserved, their interpretation remains doubtful without etching in disodium salt. Nevertheless, in some specimens (Fig. 4N, probably also 4L) discernable lamination sub-parallel with the surface has been observed. In these samples, the laminae probably correspond to the original exoskeletal structure, but no detailed structures are visible at higher magnifications and the exoskeleton is rather homogeneous (for similar observations in Bohemian phacopids, see Kasan 1997). Significant in this respect is an unfortunately indeterminable, minute exoskeletal fragment (Fig. 2B) of a thick-shelled dalmanitid, stygidinid or phacopid trilobite found in thin section, which was originally believed to be a poorly preserved exoskeleton of Zlichovaspis (Z.) rugosa laura from Branžovy. In this fragment, fairly perceptible fine pores penetrating the exoskeleton occur particularly close to the spiny granules. More interesting, however, is a thin, comparatively clear layer composed of recrystallised calcite (confirmed by ob- 

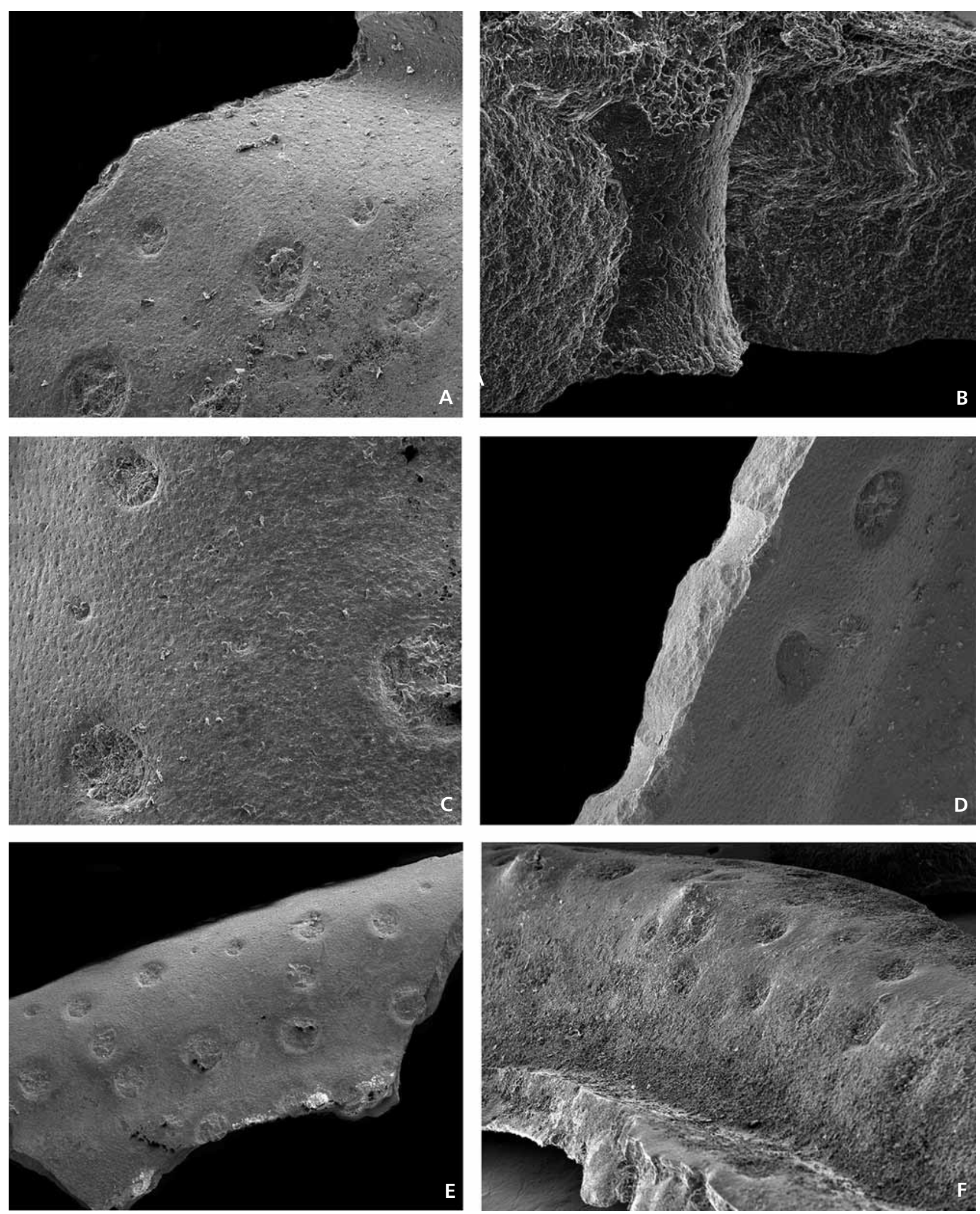

Figure 3. A-F-Zlichovaspis (Devonodontochile) maccoyi (Barrande, 1852), Zlíchov Formation (Lower Devonian, lower Emsian = Zlichovian Stage). Lužce, CGS JV 3535. Surface of exoskeleton of left $7-8^{\text {th }}$ pygidial ribs (A, E-F), and its section (D) showing distinctive perforation of all elevated parts of the exoskeleton by megapores. Every megapore has its own individual peripheral mound, the prominence of which varies among individuals and exoskeletal areas. However, their general structure is relatively uniform. A $-\times 64, \mathrm{D}-\times 48, \mathrm{E}-\times 32, \mathrm{~F}-\times 37 . \bullet \mathrm{B}-$ detail of megapore filled by sediment. $\times 265 . \bullet \mathrm{C}-$ together with megapores, and the second-order, extremely fine perforation of the exoskeleton is visible in the left part of the image. $\times 80$. 
servations in polarised light), which is present in the uppermost exoskeletal layer. This thin layer, reaching inside the spiny granules, apparently bears a different structure than the other remnants of the exoskeleton, which are massive and homogeneous. Whether this thin layer represents the recrystallised outer zone of the principal layer, or is only a diagenetic structure (see McAllister \& Brand 1989) originating at the boundary of different rock types (a micritic and sparitic part), is uncertain. In this specimen and in the majority of other samples, however, the prominent structures roughly sub-parallel with the original exoskeletal surface (also Figs 1F, I, 2C), but also of a diagonal course (Fig. 1J), were probably caused by pressure accompanying the polishing of the sample, and almost surely do not reflect the original exoskeletal composition. Only some of the samples show several other fine structures, especially penetration by fine (Figs 1C, 2B) or larger pores (especially in the middle of some of the thorn-like spines). The presumable fine pores are strongly reminiscent of the pore channels discussed by Dalingwater \& Miller (1977) and Teigler \& Towe (1975); penetration of the spines and thorn-like granules in Bohemian Lower Devonian dalmanitids was also discussed by Šnajdr (1987).

An entirely different situation is found in the material of the subgenus Zlichovaspis (Devonodontochile) Šnajdr, 1985. In all samples, the prominent perforation of the exoskeleton by megapores is observed to be very well preserved in thin sections (Figs 1E, 2F) and in exoskeletal fragments examined under electron microscope (Fig. 3A-F). These megapores show an overall cylindrical to hyperboloid cross section and are filled by sediment, as observed by Šnajdr $(1985,1987)$. Every megapore is surrounded by a low peripheral mound perceptible particularly on the outer side, but present also on inner side of the exoskeleton. These peripheral mounds are especially prominent in Zlichovaspis (Devonodontochile) vigerle Šnajdr, 1987. However, the diameter of the megapores (varying mostly between 0.35 and $0.1 \mathrm{~mm}$ ) and the convexity of their pe- ripheral mounds vary markedly even in the same specimen. The widest megapores are present on the elevated parts of exoskeleton, whereas their quantity and diameter rapidly decrease toward the depressions and furrows, where they gradually disappear. Larger and smaller megapores, however, may occur together in the same exoskeletal areas (well demonstrated in Fig. 3E). In addition to the megapores, dense fine imprints are also perceptible on the external exoskeleton surface of some specimens, representing probable fine punctations or perforations of a second order (see Fig. 3C). The density and prominence of these fine imprints or pores is rather uniform. Extremely fine perforation, attaining a density of 200-250 pores per $\mathrm{mm}^{2}$, were also described by Šnajdr (1987) in Bohemian representatives of Reussiana Šnajdr, 1987. However, these "pores" in both Zlichovaspis (Devonodontochile) and Reussiana are perceptible on the upper exoskeletal surface only. No traces of these pores were observed to persist very far inside the exoskeleton, as this dense punctation is seen to quickly disappear in the thin sub-surface layer in thin sections and electron microscope samples. However, because the inner structures of the exoskeleton in most of the material are almost completely effaced by recrystallisation, these structures are still considered as pores because of their characteristic shape. Similar but slightly coarser punctations that are about $15 \mu \mathrm{m}$ in diameter and visible in the outer zone of the principal exoskeletal layer were described in Ellipsocephalus Zenker, 1833 by Dalingwater et al. (1991).

Interpreting the biological function of both structures is of considerable interest. The fine punctations or pores probably represent sites of sensor attachment for receptors analogous to the bothria in arachnids (Meslinger 1987) and other arthropod groups. The megapores, however, seem too large to be opening for isolated setae or similar organs. Their preferential occurrence in the elevated part of exoskeleton suggests their function as receptor sites. It is interesting to note that young (meraspid and early

Figure 4. A-E-Odontochile cristata Hawle \& Corda, 1847, Praha-Konváŕka. $\bullet$ A-B - a detail of the small rounded conical granules on $6^{\text {th }}$ left pygidial rib, lateral and dorsal view. CGS PB 206. $\times 106 . \bullet C, E-$ a hypostome exoskeleton showing prominent posterior spines and very fine basic granulation, coarser close to the posterior hypostome margin, CGS JV 3534. C $-\times 14, \mathrm{E}-\times 21 . \bullet \mathrm{D}-$ part of $6^{\text {th }}$ left pygidial rib showing dense, fine, slightly differentiated granulation, but no spines or thorn-like granules, $\times 13$, CGS PB 206. $\bullet$ F - Zlichovaspis (Devonodontochile) vigerle (Šnajdr, 1987), Švagerka, CGS PB 207. A thin hypostome exoskeleton with prominent but sparse, mostly hollow, thorn-like granules, $\times 16$. $\bullet$ G-J - Zlichovaspis (Z.) rugosa laura Šnajdr, 1985, Branžovy near Loděnice, CGS PB 208. • G - a cross-section through the exoskeleton of a left pygidial rib (above) and pygidial doublure (below), showing the homogeneous structure of the original exoskeleton (probably recrystallised). $\times 32$. $\bullet \mathrm{H}-\mathrm{a}$ detail of almost smooth surface of the pygidial doublure affected by recrystallisation. $\times 53$. $\bullet \mathrm{I}$ - changes in the exoskeleton sculpture from a smooth ventral doublure surface toward the pygidial margin. $\times 21$. $\bullet \mathrm{J}-$ a detail of the fine thorn-like granules with sparse larger but broken granules to spines on the pygidial ribs. $\times 21$. $\bullet \mathrm{K}$, L, $\mathrm{N}-$ Zlichovaspis (Z.) vaneki nom. nud., Čeřinka Quarry near Bubovice, ex JV 3511. $\bullet \mathrm{K}-$ general view of an exoskeletal fragment from pygidial ribs and part of axial rings, shows smooth surface with larger sporadic granules to short spines. $\times 11$. $\bullet$ L - a cross-section through the exoskeleton showing indistinct lamination. $\times 32 . \bullet N$ - a detail of indistinct lamination. $\times 106 . \bullet$ M - Zlichovaspis (Devonodontochile) vigerle (Šnajdr, 1987), CGS PB 207 (coll. J. Vaněk), Švagerka. A cross section through the thin hypostome exoskeleton with sparse thorn-like hollow granules and rare megapores (see Fig. 4F). $\times 27$. All specimens are from the Praha Formation (Lower Devonian, Pragian Stage), except for F and K-M, which are from the Zlíchov Formation (Lower Devonian, lower Emsian = Zlichovian Stage). 
Petr Budil \& František Hörbinger • Exoskeletal structures in Devonian dalmanitid trilobites
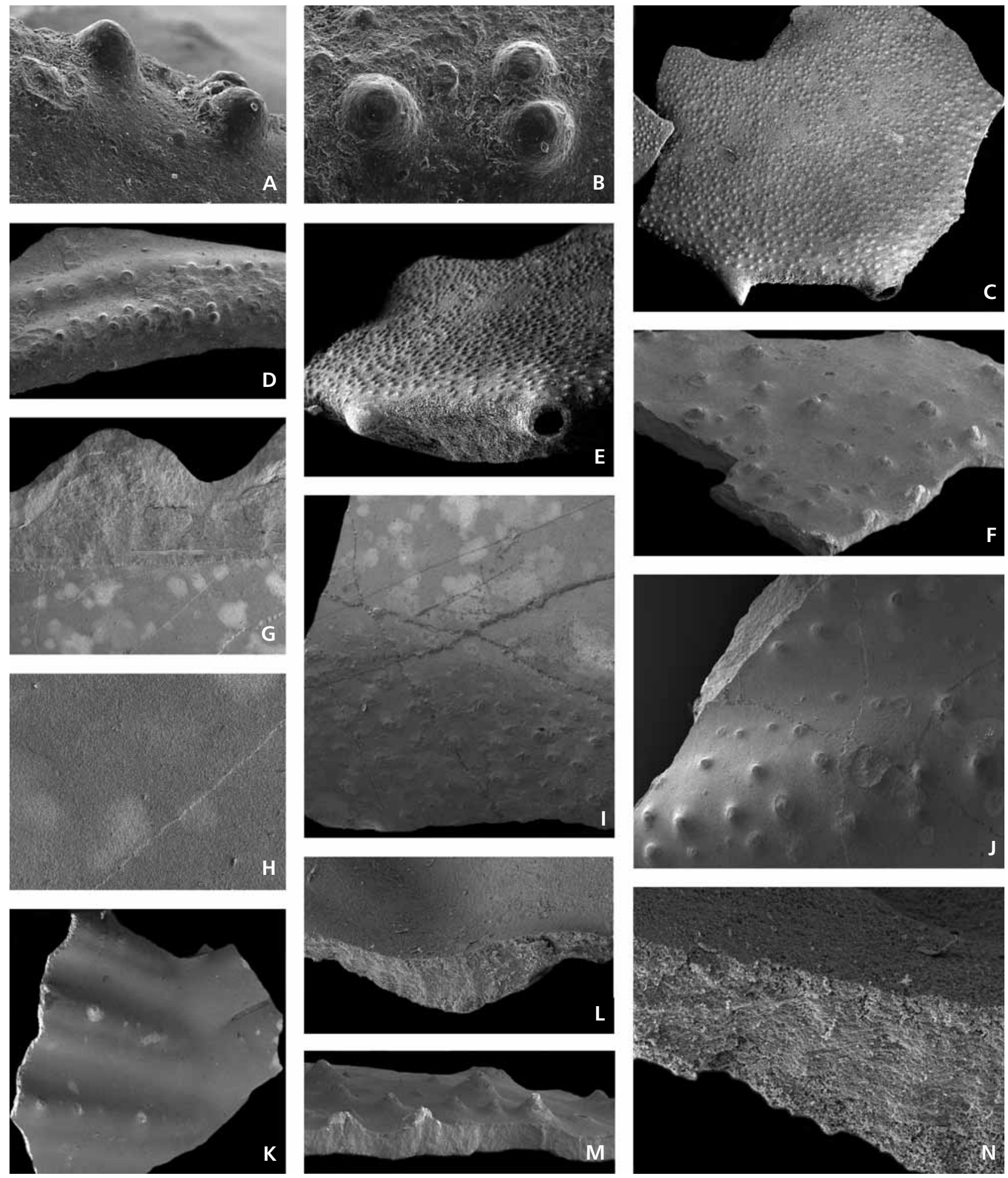
holaspid) specimens of Devonian dalmanitids also possess such perforation, but it is very fine, with diameters less than $0.1 \mathrm{~mm}$ and lying inside the pleural and interpleural furrows. Relatively homogeneous but extremely fine perforation (diameters less than $0.1 \mathrm{~mm}$ ) apparently of the entire cephalon has been recently observed by Budil et al. (in press) within the interspaces between coarse granules of some young specimens of Zlichovaspis (Z.) auriculata (Dalman, 1826). But these pores are not identical to megapores, two principal differences being that they lack the peripheral mound and their diameters are much smaller. Whether the megapores represent openings of the exoskeleton for large spiny setae or setal bundles that served as sensors is highly speculative. Somewhat disputable interpretation is that they were attachment sites of movable spines that served for the physical protection of the animal or for mimicry (for a discussion of mimicry in trilobites, see Kácha \& Petr 1995). In all cases, the presence of megapores is a prominent feature, characteristic of the latest representatives of the family Dalmanitidae in the Prague Basin pertaining to the subgenus Zlichovaspis (Devonodontochile) Šnajdr, 1985. However, analogous structures also occur in a few North American dalmanitaceans (some species of Bellacartwrightia Lieberman \& Kloc, 1997 or Greenops Delo, 1935, see Whiteley et al. 2002).

\section{Remarks on the eye structures}

In conjunction with the study of inner exoskeletal structures, several thin sections of the large schizochroal eyes of Odontochile hausmanni (Brongniart, 1822) were made (see Fig. 1I-O). In all of these thin sections, we observed the well preserved characteristic structure of the schizochroal eyes that have been described and discussed in detail by Clarkson (1967, 1968, 1969, 1971, 1975), Campbell (1977), Miller \& Clarkson (1980), Horváth \& Clarkson (1993), and Levi-Setti (1993). The large massive lenses separated by interlensal sclera are visible in each thin section. The internal structure of the separate lenses is partially effaced by recrystallisation. Nevertheless, the structures that seem to be longitudinal and transversal inner growth lamellae are observable. Other structures, such as alveolar rings, girdles and what seem to be the remains of the endocuticular fabric, are also relatively well preserved. However, perhaps with the exception of the right lens shown in Fig. 1K, L, where some structures seem to be present, no unquestionable traces of lens cores and/or intralensal bowls were observed. The absence of these features may be explained by recrystallisation, though Bruton \& Haas (2003) presented an alternative explanation in which the intralensal bowls are products of diagenesis. In the specimen shown in Fig. 1K, the thin dark layer apparently covers the surface of the lenses and is probably fused with the interlensar scleras reminiscent of the (?) corneal membrane. Below every lens of this specimen, a thin but perceptible layer of unknown origin, so far not discussed in the literature, occurs. In the specimen pictured in Fig. 1O, a different uniform, thick, white layer apparently covers and separates the lenses (part of lenses are probably broken and slightly displaced). In this case the eye has probably been affected by diagenetic and tectonic alteration.

\section{Secondary structures}

Despite diagenetic and possible tectonic modification (Fig. 1I, O), micritisation features are very common among the secondary structures, particularly in material coming from the shallow-water sceletal limestones. An example of this is shown in Fig. 2A, in which apparent traces of boring by cyanobacteria are visible along with the micritisation structures. In the specimen pictured in Fig. 2E, the original exoskeleton is intensely corroded, and large caverns seem to have originated by partial solution of the exoskeleton or by bacterial activity.

\section{Discussion}

The observations and remarks made in the present paper and by other authors (e.g., Clarkson 1968, 1969, 1971 and Kasan 1997) suggest the need of a general systematic investigation of the exoskeletal structures in dalmanitid and phacopid trilobites, as well as in the other trilobite groups of the Prague Basin. Although comparison with better preserved material is limited due to recrystallisation, the fine morphological structures observed here should generally encourage future investigations. However, a preliminary electron microscope investigation by the first author indicates that the preservation of material in Ordovician clastic rocks or siliceous nodules is, with the exception of eye structures, too poor for exact observations of exoskeletal ultrastructure. The Silurian and Devonian material seems to be better preserved and offers more potential.

\section{Acknowledgements}

The Czech Science Foundation - Grant Agency of the Czech Republic (GAČR) supported this contribution through Grant Project 205/04/P026 "The Lower Devonian Dalmanitid Trilobites of the Prague Basin". We would like to express many thanks to J. Frýda, O. Fatka, Š. Manda and J. Král for very useful discussions about the manuscript. We also would like to especially thank E.N.K. Clarkson and R.M. Owens for their very valuable comments on the manuscript. J. Frýda, J. Haloda, and J. Malec assisted with the electron microscope photographs. The thin sections were made by J. Letko and A. Tichá. 


\section{References}

BARRANDE, J. 1846. Notice préliminaire sur Système Silurien et les trilobites de Bohême. 96 pp. Leipzig.

BARRANDE, J. 1852. Système Silurien du centre de la Bohême. Ière partie. Recherches paléontologiques. I. Trilobites. 935 pp. Praha and Paris.

Brongniart, A. 1822. Les trilobites, 1-65. In Brongniart, A. \& Desmarest, A.G. (eds) Histoire naturelle des crustacés fossiles: Les trilobites. Paris.

BRUton, D. \& HAAS, W. 2003. The puzzling eye of Phacops. Special Papers in Palaeontology 70, 349-361.

Budil, P., Hörbinger, F. \& Menzel, R. In press. Lower Devonian dalmanitid trilobites of the Prague Basin (Czech Republic). Transactions of the Royal Society of Edinburgh.

CAMPBEll, K.S.W. 1967. Henryhouse trilobites. Bulletin of Oklahoma Geological Survey 115, 1-68.

CAMPBELL, K.S.W. 1975. The functional anatomy of phacopid trilobites: musculature and eyes. Journal and Proceedings, Royal Society of New South Wales 108, 168-188.

CampBell, K.S.W. 1977. Trilobites of the Haragan, Bois d'Arc and Frisco Formations (Early Devonian), Arbuckle Mountains region, Oklahoma. Bulletin of the Oklahoma Geological Survey $123,1-139$.

CHLuPÁČ, I. 1977. The phacopid trilobites from the Silurian and Devonian of Czechoslovakia. Rozpravy Ústředního ústavu geologického 43, 1-172.

Clarkson, E.N.K. 1967. Fine structure of the eye in two species of Phacops (Trilobita). Palaeontology 10, 603-616.

Clarkson, E.N.K. 1968. Structure of the eye of Crozonaspis struvei (Trilobita, Dalmanitidae, Zeliszkellinae). Senckenbergiana Lethaea 49, 367-381.

Clarkson, E.N.K. 1969. On the schizochroal eyes of three species of Reedops (Trilobita: Phacopidae) from the Lower Devonian of Bohemia. Transactions of the Royal Society of Edinburgh 68(8), 183-205.

Clarkson, E.N.K. 1971. On the early schizochroal eyes of Ormathops (Trilobita, Zeliszkellinae). Mémoires du Bureau de recherches géologiques et minières 73, 51-63.

Clarkson, E.N.K. \& LeVI-Setti, R. 1975. Trilobite eyes and the optics of Des Cartes and Hughes. Nature 254(5502), 663-667.

DALingWATER, J.E. 1973. Trilobite cuticle microstructure and composition. Palaeontology 16, 827-839.

Dalingwater, J.E. \& Miller, J. 1977. The laminae and cuticular organization of the trilobite Asaphus raniceps. Palaeontology 20, 21-32.

Dalingwater, J.E., Hutchinson, S.J., Mutvei, H. \& Siveter, D.J. 1991. Cuticular ultrastructure of the trilobite Ellipsocephalus polytomus from the Middle Cambrian of Öland, Sweden. Palaeontology 34, 205-217.

Dalingwater, J.E., Hutchinson, S.J., Mutvei, H. \& Siveter, D.J. 1993. Cuticular ultrastructure of some Silurian calymenid trilobites from the Welsh Borderland and Gotland. Palaeontographica, Abteilung A 229, 37-49.

DALMAN, J.W. 1826. Om palaeaderna, eller de sa kallade trilo- biterna. Konliga Svenska Vetenskaps-Akademiens Handlingar 1826, 113-294.

DELO, D.M. 1935. A revision of the phacopid trilobites. Journal of Paleontology 9(5), 402-420.

Fortey, R. \& OWENS, R. 1999. The trilobite exoskeleton, 538-562. In SAVAZZI, E. Functional Morphology of the Invertebrate Skeleton. John Wiley and Sons Ltd., London.

Fortey, R.A. \& WiLmot, N.V. 1991. Trilobite cuticle thickness in relation to palaeoenvironment. Paläeontologische Zeitschrift 65, 141-151.

GILL, E.D. 1949. Prosopon, a term proposed to replace the biologically erroneous term ornament. Journal of Paleontology $23,572$.

Hawle, I. \& CoRDA, A.J.C. 1847. Prodrom einer Monographie der Böhmischen Trilobiten. 176 pp. Praha.

Horváth, G. \& Clarkson, E.N.K. 1993. Computation Reconstruction of the Probable Change of Form of the Corneal Lens and Maturation of Optics in the Post-ecdysial Development of the Schizochroal Eye of the Devonian Trilobite Phacops rana milleri Stewart 1827. Journal of Theoretical Biology 160(3), 271-405.

KÁCHA, P. \& Petr, V. 1995. Camouflage and mimicry in fossils, I.: General part. Acta Musei nationalis Pragae, Series B historia naturalis 51(1-4), 53-82.

KAESLER, R.L. 1997. Ed. Treatise on Invertebrate Paleontology, Part O, Arthropoda 1 Trilobita. 535 pp. Geological Society of America, University of Kansas Press, Lawrence, Boulder.

KASAN, D. 1997. Variabilita tuberkulace trilobitů podrodu Phacops (Boeckops) Chlupáč, 1971 a rodu Chotecops Chlupáč, 1971 devonu Barrandienu. 72 pp. Master thesis, Charles University, Praha.

Levi-Setti, R. 1993. Trilobites. Second edition. 342 pp. The University of Chicago Press, Chicago.

LIEBERMAN, B.S. \& KLOC, G.J. 1997 Evolutionary and biogeographic patterns in the Asteropyginae (Trilobita, Devonian) Delo, 1935. Bulletin of the American Museum of Natural History 232, 1-127.

LINDSTRÖM, G. 1901. Researches on the visual organs of the trilobites. Konliga Svenska Vetenskaps-Akademiens Handlingar 34(8), 1-86.

Meslinger, K. 1987. Fine structure of scorpion trichobothria (Arachnida, Scorpiones). Zoomorphology 107, 49-57.

MCAllister, J.E. \& BRAND, U. 1989. Primary and diagenetic microstructures in trilobites. Lethaia 22, 101-111.

Miller, J. 1976. The sensory fields and life mode of Phacops rana (Green, 1832) (Trilobita). Transactions of the Royal Society of Edinburgh 69(16), 337-367.

Miller, J. \& Clarkson, E.N.K. 1980. The postecdysial development of the cuticle and the eye of the Devonian trilobite Phacops rana milleri Stewart 1927. Philosophical Transactions of the Royal Society of London, Series B 288, 461-480.

MutveI, H. 1981. Exoskeletal structure in the Ordovician trilobite Flexicalymene. Lethaia 14, 225-234.

OSMÓLSKA, H. 1975. Fine morphological characters of some Upper Palaeozoic trilobites. Fossils and Strata 4, 201-207. 
REED, F.R. 1905. The classification of the Phacopidae. Geological Magazine 42, 172-178, 224-228.

RiCHTER, R. \& RichTER, E. 1925. Unterlagen zum Fossilium Catalogus. Trilobitae III. Senckenbergiana 7(6), 239-244.

ŠNAJDR, M. 1980. Bohemian Silurian and Devonian Proetidae (Trilobita). Rozpravy Ústředního ústavu geologického 45, 1-324.

ŠNAJDR, M. 1985. Bohemian representatives of the subfamily Odontochilinae subf. nov. Věstník Ústředního Ústavu geologického 60, 165-169.

ŠNAJDR, M. 1987. Bohemian Lower Devonian Odontochilinae (Trilobita). Sborník geologických věd, Paleontologie 28, 9-60.

STøRMER, L. 1930. Scandinavian Trinucleidae: With special references to Norwegian species and varieties. Skrifter Utgitt av Der Norsk Geologisk Tidsskrift 19, 143-274.

STØRMER, L. 1980. Sculpture and microstructure of the exoskeleton in chasmopid and phacopid trilobites. Palaeontology 23, 237-271.
TeIGLER, D.J. \& Towe, K.M. 1975. Microstructure and composition of the trilobite exoskeleton. Fossils and Strata 4, 137-149.

WiLmot, N.V. 1990a. Cuticular structure of the agnostine trilobite Homagnostus obesus. Lethaia 23, 87-92.

WiLMOT, N.V. 1990b. Primary and diagenetic microstructures in trilobite exoskeletons. Historical Biology 4, 51-65.

WILMOT, N.V. \& FALLICK, A.E. 1989. Original mineralogy of trilobite exoskeletons. Palaeontology 32, 297-304.

Whiteley, T.E., Kloc, G.J. \& BReTt, C.E. 2002. Trilobites of New York. 202 pp. Cornell University Press, Ithaca.

ZENKER, J.C. 1833. Beiträge zur Naturgesichte der Urwelt. Organische Reste (Petrefacten) aus der Altenbruger BraunkohlenFormation, dem Blankenburger Quadersandstein, Jenaischen bunten Sandstein und Böhmischen Uebergangsgebirge. 67 pp. Jena. 